\title{
THE HISTORICAL ANTHROPONYMY OF THE RUTHENIAN POPULATION LIVING IN THE HISTORICAL TERRITORIES OF THE EASTERN LUBLIN REGION (ON THE MATERIAL OF REGISTERS OF PARISHES IN THE FORMER GREEK-UNIATE DIOCESE OF CHEŁM)
}

\author{
Marcin Kojder \\ Uniwersytet Marii Curie-Skłodowskiej w Lublinie \\ ORCID: 0000-0001-7002-9552
}

\begin{abstract}
Summary. The subject of research is the anthroponymy of the Ruthenian (Ukrainian) population living in the historical territories of the eastern Lublin region on the Polish-East-Slavic borderland. The underlying objective of the study was to investigate the Ruthenian onomastics functioning in the historical Polish-Ukrainian onomastics and to highlight the territorial diversification of the personal names of Ukrainians, related to the dialectal diversity in the studied territory. The reference database is personal proper names excerpted from the parish registers of Uniate parishes in the former Chełm diocese. The territory investigated was divided into three areas: northern, central and southern, based on the ranges of the Ukrainian dialects spoken in the territory of present-day Poland. The research material was excerpted from the records of Uniate parishes in the former Chełm diocese in the years of 1662-1810.

The northern area, defined by the range of Podlasie local dialects, and the central area, determined by the ranges of transitional dialects from northern to southern ones and Volhynian dialects, exhibit features closely similar to peasant anthroponymy, while the southern area, defined by the ranges of Dniester and San dialects, presents features characteristic of the anthroponymy of the lower Ukrainian gentry.
\end{abstract}

Key words: personal proper name, historical anthroponymy, Ukrainian anthroponomy, Polish-East-Slavic borderland, Greek-Uniate Diocese of Chełm

The subject of research is the anthroponymy of the Ruthenian (Ukrainian) population living in the historical territories of the eastern Lublin region on the Polish-East-Slavic borderland in the broad sense. The underlying objective of the study was to investigate the Ruthenian onomastics functioning in the historical Polish-Ukrainian onomastics and to highlight the territorial diversification of the personal names of Ukrainians, related to the dialectal diversity in the studied territory. The reference database is personal proper names excerpted from the parish registers of Uniate parishes in the former Chełm diocese.

The Greek-Uniate dioceses of Chelm existed from the adoption of the Union of Brest in 1596 until 1875, when it was abolished by the Russian au- 
thorities. The Uniate parish network covered the then Chelm land, part of the Bełz province, and part of the Lublin province. The studied area comprises the eastern part of the contemporary Lublin province, and the northern parts of the Podkarpackie province ${ }^{1}$.

The territory investigated was divided into three areas: northern, central and southern, based on the ranges of the Ukrainian dialects spoken in the territory of present-day Poland. The three defined areas correspond to the following dialectal sets of the Ukrainian language: the northern area - Podlasie dialects (northern dialect) ${ }^{2}$; the central area - to Volhynia-Chełm dialects and transitional dialects from northern to south-western ones (south-western dialect) ${ }^{3}$; the southern area - Dniester dialects (Opole dialects) in the eastern part and to San dialects in the western part (south-western dialect) ${ }^{4}$.

The research material was excerpted from the records of Uniate parishes in the former Chelm diocese in the years of 1662-1810. Most of this material had not been studied from the onomastic perspective. The oldest records, dated to 1662-1778, are written in Ruthenian, usually in the Cyrillic script, while the later records were written in Latin (from 1714) or in Polish (from 1765). The assumed temporal framework of the study was defined by the years 1596 and 1810, or the period from the conclusion of the Union of Brest to the introduction of the Napoleonic (i.e. civil) Code. The oldest documents available in this collection date back to 1662 .

The type and nature of researched sources influenced the fact that the analyzed linguistic material consist only Christian names, mostly belonging to the Orthodox Church canon. In the research material there are 154 male names in over 7700 evidence items and 83 female names in over 4600 items. The material excerpted from the sources is presented in the form of male given names and women's given names, taking the territorial context into consideration.

The historical anthroponymy of the faithful of the Greek-Uniate Chełm diocese during the studied period was dominated by the patronymic type, which is consistent with the studies of other areas inhabited by the Ruthenian population $^{5}$. These formations account for $47 \%$ of all male surnames. They were

A. Gil, Chetmska diecezja unicka 1596-1810. Dzieje i organizacja, Lublin 2005, p. 42.

М. Лесів, Украйнські говірки у Польщі, Варшава 1997, с. 279-291; F. Czyżewski, S. Warchoł, Polskie i ukrainskie teksty gwarowe ze wschodniej Lubelszczyzny, Lublin 1998, p. XXXVII.

M. Лесів, op. cit., s. 239-249; F. Czyżewski, S. Warchoł, op. cit., p. XXXVII.

M. Лесів, op. cit. s. 223-225; F. Czyżewski, S. Warchoł, op. cit., p. XXXVII.

L. Citko, Nazewnictwo osobowe pótnocnego Podlasia w XVI wieku, Białystok 2001;

L. Dacewicz, Historia nazwisk na kresach pólnocno-wschodnich Rzeczypospolitej: XV-XIX wiek, Białystok 2014; I. Mytnik, Antroponimia Wotynia w XVI-XVIII wieku, Warszawa 2010; eadem, Imiennictwo ziemi chetmskiej w XVI-XVII wieku, Warszawa: 2017; M. Kojder, Antroponimia historyczna starostwa hrubieszowskiego w XVII i XVIII wieku, Lublin 2014; idem, 
formed by means of 10 derivational morphemes (suffixes): -owicz/-ewicz; $-u k /-u k /-c z u k ;-i k /-y k /-c z y k ;$ - ak; -ko/-enko; -ek/-ok; -ka; -ec; -uch; -ew/-ow; $-i n /-y n^{6}$. The second largest group of surnames was those equal to appellatives $-22.8 \%$ of the surnames ${ }^{7}$. The third group of surnames in the studied material is composed of place-name surnames, which constitute $16.6 \%$ of all the material. The vast majority of place-name surnames are formed with the suffix -ski/-cki ${ }^{8}$. The place-name surnames also include the surnames equal to the names of inhabitants of towns/villages, derived with noun suffixes -ak, -(an) $i c a,-a n i n,-e c,-i k /-y k,-u k^{9}$. The surnames equal to given names and those derived from given names account for $7.8 \%{ }^{10}$, and surnames equal to the names of occupations constitute $4.7 \%$ of the total number of names ${ }^{11}$. The numerically smallest group of surnames is the surnames equal to ethnic names: they accounted for a negligible portion of the research material - altogether $1.2 \%{ }^{12}$.

All the female anthroponyms were divided into two main groups: those based on husbands' surnames and on fathers' surnames. The third group were surnames paradigmatically derived from male surnames by means of the $-a(j a)$ ending added to place-name surnames ending in -ski/-cki and to male deappellative, adjectival surnames. The suffix - ska/-cka derived $11.9 \%$ of forms ${ }^{13}$. Among the surnames based on husbands' surnames, the most productive are two derivational morphemes: - owa $(32 \%)^{14}$ and -icha/-ycha $(38.4 \%)^{15}$. The $-k a$ suffix formed $18.8 \%$ of all surnames based on husbands' surnames ${ }^{16}$. The suffix -ina/-yna formed only $1 \%$ of such names ${ }^{17}$.

Feminine patronymic formations were derived by means of feminine patronymic morphemes. The largest group of feminine patronymic surnames

Antroponimia historyczna wiernych chetmskiej diecezji grecko-unickiej (1662-1810), Lublin 2019; M. Olejnik, Antroponimia starostwa grabowieckiego (XVI-XVIII w.), Lublin 2019; J. Rieger, Imiennictwo ludności wiejskiej w ziemi sanockiej i przemyskiej $w X V$ w. Wrocław 1977; B. Tichoniuk, Antroponimia południowej Białostocczyzny w XVI wieku, Opole 1988; E. Wolnicz-Pawłowska, Osiemnastowieczne imiennictwo ukraińskie $w$ dawnym województwie ruskim, Wrocław 1978; eadem, Antroponimia temkowska na tle polskim i stowackim, Warszawa 1993; P. Złotkowski, Antroponimia historyczna mieszczan i chłopów Brańska i okolic w ujęciu statycznym i dynamicznym, Lublin 2017.

$6 \quad$ M. Kojder, Antroponimia historyczna wiernych chetmskiej diecezji..., p. 105-148.

7 Ibidem, p. 148-164.

$8 \quad$ Ibidem, p. 164-167.

$9 \quad$ Ibidem, p. 167-200.

10 Ibidem, p. 212-220.

11 Ibidem, p. 220-228.

12 Ibidem, p. 231-234.

13 Ibidem, p. 236-242.

14 Ibidem, p. 242-254.

15 Ibidem, p. 254-266.

16 Ibidem, p. 266-271.

$17 \quad$ Ibidem, p. 271-272. 
was formed by the suffix -anka, altogether $64 \%$ of the recorded forms ${ }^{18}$. The suffix -ownal-ewna (also in the Ukrainian phonetic variant -iwna) formed $33.9 \%$ of feminine patronymic surnames ${ }^{19}$. The third group of feminine patronymics was created by the $-k a$ suffix, recorded in over a dozen used, at the level of $2.1 \%{ }^{20}$.

In the studied material there is a small group of women's surnames equal to male surnames. These are noun-based surnames equal to surnames formed without morphological exponents, as well as to patronymic surnames ending in -owicz and $-u k^{21}$. The occurrence of women's surnames equal to male surnames is the initial stage in the development of a female surname ${ }^{22}$.

During the period under study, the anthroponymic system tended to stabilize in the form of two-element names in accordance with the first name + surname pattern. The majority of identification formulas consist of a given name and surname derived semantically or through word formation although there are also few examples of the use of simple surnameless formulas or more extensive, two- and three-element anthroponymic descriptions. The archival sources investigated contain many examples of expressions referring to married couples. Collective names in the plural were most often used for the purpose. The occurrence of collective surnames embracing whole families is evidence of the stability of their form and function. During the period in question, the priests were a privileged class. The high social position of priests and their families is reflected in personal onomastics. Among the representatives of the Uniate clergy there was an exceptionless compulsory two-element naming pattern containing a first name and a place-name surname ending in $-s k i$ $(58 \%)$ or a patronymic surname in -owicz/-ewicz $(42 \%)^{23}$.

Proper names, particularly oikonyms and anthroponyms, are the level of language at which historical linguistic processes are reflected ${ }^{24}$. The historical anthroponymy of the 17th and 18th century, which is a category in statu nascendi, reflects a whole array of linguistic phenomena characteristic of the language of the period. The investigated territory was largely inhabited by the Ukrainian population who predominantly spoke Ukrainian. Bilingualism

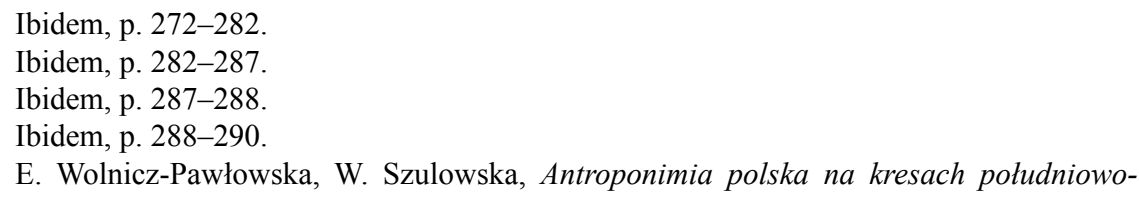

E. Wolnicz-Pawłowska, W. Szulowska, Antroponimia polska na kresach poludniowo-wschodnich, Warszawa 1998, p. 226-232; L. Dacewicz, Rola sufiksu -uk w kulturze nazewniczej Podlasia, [in] Manuscula Linguistica In Honorem Aleksandrea Cieślikowa oblata. eds. Kazimierz Rymut. Kraków 2006, p. 277-278, C.М. Пахомова, Еволюиія антропонімних формул у слов'янських мовах, Ужгород 2012 , p. 54.

23 M. Kojder, Antroponimia historyczna wiernych chetmskiej diecezji..., p. 302-303.

24 Z. Kaleta, Nazwisko w kulturze polskiej, Warszawa 2006, p. 64. 
among that population was confined to the upper echelons of the Uniate clergy and bourgeois elites. The rural and town population was mostly monolingual: they spoke local dialects of Ukrainian ${ }^{25}$. The Ukrainian local dialects functioning in the studied area remained within two dialects of Ukrainian: North Ukrainian and South-Western Ukrainian ${ }^{26}$.

The starting point for the division of the investigated territory into three areas in accordance with the ranges of the dialectal sets was the definition of a local dialect (inter alia by Karol Dejna ${ }^{27}$ ). The original ranges of dialectal sets are closely connected with the early settlement process in a given area. The Ruthenian ethnos in these areas has been present since the tribal period and is a kind of substratum, on which other elements were superimposed in the subsequent period: the Polish one resulting from Mazovian colonization (on the whole territory) and the Wallachian as a result of Wallachian colonization in the 16th century (in the southern area) ${ }^{28}$. In contrast, the Ruthenian population did not mix with populations in other regions and remained in their original locations.

Diversity within phonetic phenomena was discussed based on phonetic features characteristic of West-Ukrainian dialects present in the archival material. The presence and different ranges of certain dialectal features provide grounds for their division into three separate areas. The following phonetic phenomena, typical of West-Ukrainian dialects, were taken into consideration: ikavism, substitution of the $x, x v$ sounds for the $f$ consonant, substitution of $p$ for the $f$ sound, substitution of the initial $g m$ - for the $d m$ - group, alternation in $w-u$ vowels, the narrowing of the $e$ vowel to $i$, narrowing of $e$ to $y$, the narrowing of the vowel $o$ to $u$, and the occurrence of prosthetic vowels ${ }^{29}$.

The regional diversity of the studied material is best seen in the field of word-formation. This is about both the proportion of individual types of male surnames and the regional ranges of the developed word-formation patterns within particular surname types, mainly male patronymic surnames and female patronymic and maritonymic surnames.

The most conspicuous are regional divergences regarding patronymic surnames and those equal to appellatives. In the northern area, patronymic surnames are the largest group of names, accounting for as much as $66.5 \%$, whereas in the southern area the percentage of patronymic surnames is only $33.7 \%$. In the central area, patronymic surnames constitute $48.2 \%$. Different

25 J. Kość, Polszczyzna poludniowokresowa na polsko-ukraińskim pograniczu językowym w perspektywie historycznej, Lublin 1995, p. 42.

26 F. Czyżewski, S. Warchoł, op. cit., p. XIII.

27 K. Dejna, Dialekty polskie, Wrocław-Warszawa-Kraków 1993, p. 21.

28 A. Janeczek, Osadnictwo pogranicza polsko-ruskiego. Województwo betskie od schyłku XIV do początku XVIII w., Warszawa 1993, p. 204.

29 M. Kojder, Antroponimia historyczna wiernych chetmskiej diecezji..., p. 311-318. 
results are obtained from the comparison of data on appellative surnames. This type of surnames is the most productive in the southern area (33\%), and the least in the northern area (11.2\%). The other types of male surnames (based on place-names, equal to given names, to ethnoses and to vocational names) are characterized by similar frequencies in the whole territory ${ }^{30}$.

Word-formation diversity can be seen in the regional ranges and productivity of specific word-formation types. Out of the derivational morphemes forming patronymic names the suffix -icz/-owicz/-ewicz produced a total of $17.8 \%$ surnames, its regional productivity being uneven: $12 \%$ in the northern area and $17.2 \%$ in the central. It reached the highest productivity in the southern area $(28.8 \%)$, where it is the most productive of the suffixes forming patronymic surnames. The most numerous of male patronymic surnames are those with suffixes $-u k /-c z u k$, accounting for $50.4 \%$ in this group. They also have the highest frequencies in two of the investigated areas, i.e. in the northern area (59.4\%), and similarly in the central area (61.2\%). In comparison, the southern area clearly stands out with only $9.2 \%$ patronymic surnames formed with the two suffixes. Other lower productivity suffixes forming patronymic surnames also have varied frequencies ${ }^{31}$.

Regional diversity in word-formation is also observable in the productivity of derivational morphemes forming feminine names. With regard to the productivity of the suffix $-s k a$, the central area clearly stands out where it produced almost $15 \%$ of surnames while in the other two - ca. $7 \%$ each. Out of the maritonymic surnames, two morphemes are characterized by the highest productivity: -owa (32\%) and -icha/-ycha (38.4\%). Differences in their regional ranges are substantial: the suffix -owa achieved the highest productivity in the northern area $(48.3 \%)$, while $-i c h a /-y c h a$ in the southern area $(44 \%)$. In the remaining areas their frequency is similar, ranging from $20 \%$ to $30 \%$. The suffix $-k a$ formed $18.8 \%$ of all maritonymic surnames. The slight predominance of this suffix in the southern area can be explained by the higher frequency of male vocational surnames in this region. In the southern area the highest frequency was reported for the suffix -ina/-yna. Despite being the least frequent suffix forming maritonymic surnames, its proportion in the south is five times as high as in the other areas ${ }^{32}$.

Feminine patronymic formations were largely formed by suffixes -owna/-ewna (-iwna), -anka and -ka. The largest group was produced by the suffix -anka, altogether $64 \%$ of forms. It achieved the highest productivity in the northern $(86.3 \%)$ and central $(67.6 \%)$ regions, with a far lower frequency in the south (15\%). The suffix -owna/-iwna formed $33.9 \%$ of female patro-

Ibidem, p. 319.

Ibidem, p. 320-321.

Ibidem, p. 321. 
nymic surnames, its regional distribution being the highest in the southern region $(85 \%)$, far lower in the central area $(32.4 \%)$ and slight in the north $(7 \%)$. The disproportion in the use of the derivational morphemes -owna and -anka cannot possibly be overlooked because it is $86 \%$ to $15 \%$ in the case of the suffix -owna and $7 \%$ to $85 \%$ in the case of the suffix -ank $a^{33}$.

It is the most difficult to draw conclusions about the regional diversity of anthroponymy of the Chelm Uniates on the basis of the lexis. The point is first of all the regional and local ranges of the functioning of surnames equal to appellatives, vocational names, as well as the stems of surnames derived through word-formation. Within the surnames equal to appellatives, only seven name-based surnames out of 602 recorded forms were reported in all the three areas. A certain number of forms are found parallel in two regions, e.g. in the northern and central areas there were 11 surnames, in the central and southern areas 21 surnames were reported, while in the northern and southern areas 6 surnames in common were found. It appears justified to argue that in the areas neighboring on one another more forms in common are found than in the areas apart. The vast majority of surnames equal to appellatives were recorded only in one of the studied areas: 52 only in the northern area, 183 only in the central area and 214 only in the southern area ${ }^{34}$.

The northern area, defined by the range of Podlasie local dialects, and the central area, determined by the ranges of transitional dialects from northern to southern ones and Volhynian dialects, exhibit features closely similar to peasant anthroponymy. This manifests itself in the absolute prevalence of patronymic surnames, with the dominant presence of name-based formations ending in - $u k$. A characteristic features of Podlasian anthroponymy, including the territory under study, is a large proportion of name-based surnames containing in their structure many hypocoristic forms of names with a clear prevalence of East-Slavic names ${ }^{35}$.

The southern area, defined by the ranges of Dniester and San dialects, presents features characteristic of the anthroponymy of the lower Ukrainian gentry. This manifests itself in the dominant position of patronymic surnames with the suffix -owicz, -ewicz, a larger number of patronymics with the possessive suffixes -ow/-iw, -in than in the other areas, and in a greater proportion of descriptive surnames equal to appellatives ${ }^{36}$. The foregoing conclusion does not fully identify personal onomastics in the southern area with the onomastics of boyars, but emphasizes certain onomastic traditions, more pronounced than in the other areas. Perhaps, as a result of the progressive Polonization

Ibidem, p. 321.

Ibidem, p. 323.

J. Dacewicz, Rola sufiksu..., p. 158.

36 I. Mytnik, Antroponimia Wolynia..., p. 297-301; I. Mytnik, Imiennictwo ziemi..., p. 200-203. 
of the upper echelons of the Ruthenian gentry, the naming traditions became a determinant of membership of boyar culture ${ }^{37}$.

\section{BIBLIOGRAPHY}

Citko Lilia 2001. Nazewnictwo osobowe pótnocnego Podlasia w XVI wieku. Białystok: Wydawnictwo Uniwersytetu w Białymstoku.

Czyżewski Feliks, Warchoł Stefan. 1998. Polskie i ukrainskie teksty gwarowe ze wschodniej Lubelszczyzny. Rozprawy Slawistyczne 9. Lublin: Wydawnictwo Uniwersytetu Marii Curie-Skłodowskiej.

Dacewicz LLeonarda. 2006. Rola sufiksu -uk w kulturze nazewniczej Podlasia. W: Manuscula Linguistica In Honorem Aleksandrea Cieślikowa oblata. Eds. Kazimierz Rymut. Kraków: Wydawnictwo Instytutu Języka Polskiego Polskiej Akademii Nauk: $157-162$.

Dacewicz Leonarda. 2014. Historia nazwisk na kresach pótnocno-wschodnich Rzeczypospolitej. Białystok: Wydawnictwo Uniwersytetu w Białymstoku.

Dejna Karol. 1993. Dialekty polskie. Wrocław-Warszawa-Kraków: Zakład Narodowy im. Ossolińskich.

Gil Andrzej. 2005. Chetmska diecezja unicka 1596-1810. Dzieje i organizacja. Studia i materiały do dziejów chrześcijaństwa wschodniego w Polsce. 1. Lublin: Towarzystwo Instytutu Europy Środkowo-Wschodniej.

Janeczek Andrzej. 1993. Osadnictwo pogranicza polsko-ruskiego. Województwo betskie od schytku XIV do początku XVIII w. Warszawa: Wydawnictwo Instytut Archeologii i Etnologii Polskiej Akademii Nauk.

Kaleta Zofia. 2006. Nazwisko w kulturze polskiej. Warszawa: Slawistyczny Ośrodek Wydawniczy.

Kojder Marcin. 2014. Antroponimia historyczna starostwa hrubieszowskiego w XVII $i$ XVIII wieku. Rozprawy Slawistyczne 24. Lublin: Wydawnictwo Uniwersytetu Marii Curie-Skłodowskiej.

Kojder Marcin. 2019. Antroponimia historyczna wiernych chetmskiej diecezji grecko-unickiej (1662-1810). Lublin: Wydawnictwo Uniwersytetu Marii Curie-Skłodowskiej.

Kość Józef. 1995. Polszczyzna południowokresowa na polsko-ukraińskim pograniczu językowym w perspektywie historycznej. Lublin: Wydawnictwo Uniwersytetu Marii Curie-Skłodowskiej.

Lesìv Mychajlo. 1997: Ukraïns'kì govirki u Pol'sì. Varšava: Ukraïns'kij arhìv [Лесів M., 1997. Українські говірки у Польщі. Варшава: Український архів].

Mytnik Irena. 2010. Antroponimia Wolynia w XVI-XVIII wieku. Warszawa: Katedra Ukrainistyki, Uniwersytet Warszawski.

Mytnik Irena. 2017. Imiennictwo ziemi chetmskiej w XVI-XVII wieku. Warszawa: Katedra Ukrainistyki, Uniwersytet Warszawski.

Olejnik Marek. 2019. Antroponimia starostwa grabowieckiego (XVI-XVIII w.). Lublin: Wydawnictwo Uniwersytetu Marii Curie-Skłodowskiej.

Pahomova S.M. 2012: Evolûciâ antroponìmnih formul u slov 'âns'kih movah. Užgorod: Vidavnictvo Oleksandri Arkušì. [Пахомова C.M. 2012. Еволюичія антропонімних формул у слов 'янських мовах. Ужгород: Видавництво Олександри Аркуші].

$37 \quad$ Ibidem, p. 324. 
Rieger Janusz. 1977. Imiennictwo ludności wiejskiej $w$ ziemi sanockiej i przemyskiej $w X V w$. Wrocław: Zakład Narodowy im. Ossolińskich.

Tichoniuk Bazyli. 1988. Antroponimia poludniowej Białostocczyzny w XVI wieku. Opole: Wyższa Szkoła Pedagogiczna im. Powstańców Śląskich.

Wolnicz-Pawłowska Ewa. 1978. Osiemnastowieczne imiennictwo ukraińskie $w$ dawnym województwie ruskim. Wrocław: Zakład Narodowy im. Ossolińskich.

Wolnicz-Pawłowska Ewa. 1993. Antroponimia temkowska na tle polskim i słowackim. Warszawa: Slawistyczny Ośrodek Wydawniczy.

Wolnicz-Pawłowska Ewa. Szulowska Wanda. 1998: Antroponimia polska na kresach południowo-wschodnich: $X V-X I X$ wiek. Warszawa: Slawistyczny Ośrodek Wydawniczy.

Złotkowski Piotr. 2017. Antroponimia historyczna mieszczan i chłopów Brańska i okolic w ujęciu statycznym i dynamicznym. Lublin: Wydawnictwo Uniwersytetu Marii Curie-Skłodowskiej.

\section{HISTORYCZNA ANTROPONIMIA LUDNOŚCI RUSKIEJ NA WSCHODNIEJ LUBELSZCZYŹNIE (NA MATERIALE AKT PARAFII BYŁEJ CHEŁMSKIEJ DIECEZJI GRECKO-UNICKIEJ)}

Streszczenie. Przedmiotem artykułu jest antroponimia ludności ruskiej (ukraińskiej) zamieszkującej historyczne tereny wschodniej Lubelszczyzny, czyli pogranicze polsko-wschodniosłowiańskie. Artykuł ma na celu przedstawienie historycznego imiennictwa ruskiego funkcjonującego na historycznym pograniczu polsko-ruskim oraz zwrócenie uwagi na zróżnicowanie terytorialne historycznego nazewnictwa osobowego Rusinów, pozostające $\mathrm{w}$ związku ze zróżnicowaniem dialektalnym badanego terytorium. Bazę materiałową stanowią nazwy własne osobowe wyekscerpowane $\mathrm{z}$ akt parafii unickich byłej diecezji chełmskiej z lat 1662-1810. W oparciu o zasięgi gwar ukraińskich występujących na terenie dzisiejszej Polski, badane terytorium podzielone zostało na trzy obszary: północny, centralny i południowy. Obszar północny, wyznaczony przez zasięg gwar podlaskich oraz obszar centralny, wyznaczony przez zasięgi gwar przejściowych od północnych do południowych i gwar wołyńskich, wykazują cechy zbieżne z antroponimią chłopską, zaś obszar południowy, wyznaczony przez zasięgi gwar naddniestrzańskich nadsańskich, wykazuje cechy charakterystyczne dla antroponimii niższej szlachty ruskiej.

Słowa klucze: nazwa własna osobowa, antroponimia historyczna, antroponimia ukraińska, pogranicze polsko-wschodniosłowiańskie, chełmska diecezja grecko-unicka

\section{ІСТОРИЧНА АНТРОПОНІМІЯ РУСИНСЬКОГО НАСЕЛЕННЯ НА СХІДНІЙ ЛЮБЛІНЩИНІ (НА МАТЕРІАЛІ МЕТРИЧНИХ КНИГ КОЛИШНЬОЇ ХОЛМСЬКОЇ ГРЕКО-УНІАТСЬКОЇ ЄПАРХІЇ)}

Анотація. Статтю присвячено аналізу антропонімії русинського (українського) населення, що проживало на історичних теренах східної Люблінщини, тобто на польсько-східнослов'янському пограниччі. Стаття має на меті представити історичну русинську антропонімію на історичному польсько-русинському прикордонному просторі та звернути увагу на територіальну диференціацію історичних особових 
назв русинів, що пов'язано з діалектною диференціацією досліджуваної території. Матеріал для дослідження був виписаний з метричних книг уніатських парафій колишньої Холмської єпархії 1662-1810 років. Виходячи з ареалів українських діалектів, що функціонують в сучасній Польщі, досліджувана територія була поділена на три території: північну, центральну та південну. Північна територія, що відповідає ареалу підляських говірок, і центральна територія, яка відповідає ареалу перехідних говірок від північного до південного та волинських говірок, мають риси, що відповідають селянській антропонімії, тоді як південна територія, яка відповідає ареалу придністровських говірок, має риси, характерні для антропонімії боярів.

Ключові слова: власна назва, антропонім, історична антропонімія, українська антропонімія, польсько-східнослов'янське пограниччя, Холмська греко-уніатська єпархія 